solution changes colour somewhat after a time, owing to oxidation of the ferrous salt, as Sir Wm. Ramsay tells me, and the moulds found in solutions prepared from fresh stock fluids and from others one or two months old have been of a different kind. The remarkable mould of Cladosporium type referred to in a note to my paper was found in each of a series of tubes the solutions of which had been prepared from stock fluids one month old. An examination of the stock fluids themselves, even after three months, does not reveal moulds of any kind.

H. Charlton Bastian.

Fairfield, Chesham Bois, Bucks, July 9.

\section{Napoleon and the University of Pavia.}

THE following allusion to Napoleon having spared the University of Pavia in 1804 on account of the memory of the illustrious man of science, Spallanzani, who had been a professor there, is so interesting at the present time that I venture to bring it under the notice of readers of NATURE.

The passage is from Baron's "Life of Dr. Edward Jenner" (vol. ii., p. 35), which was published in I838:- "He who flushed with victory and at the head of the revolutionary army of France had spared the University of Pavia out of respect to the genius of Spallanzani when the city itself was given up to plunder, proved that the claims of science were not forgotten amid the astonishing events which carried him forward to the highest pinnacle of ambition. His animosity to England had been shown in that vehement and decided manner which marked all his actions; yet there was one chord of sympathy unbroken which, when duly touched, showed that his intoxicating success had not raised his proud spirit beyond some of the calls of justice and humanity, and that he could still be moved by the peaceful arguments of truth and science."

Napoleon's conduct in regard to the ancient University of Pavia is in striking contrast to that of the Kaiser in regard to the University of Louvain. The Germans, in their own opinion, are pre-eminent in the subject of the history of medicine, and yet it has been reserved for Germans to destroy the University of van Helmont, the father of chemistry, of Vesalius, the father of anatomy, of Schwann, the originator of the cell-theory. Further comment seems unnecessary.

D. FRASER HARRIS.

Dalhousie University, Halifax, N.S., June I9,

\section{A New Tsetse-Fly from Zululand.}

ThE Durban Museum has lately received from $\mathrm{Mr}$. R. A. L. Brandon, the magistrate of Ubombo, Zululand, a tsetse-fly captured by him in the court-house at Ubombo, towards the end of March, which is very distinct from the ordinary Zululand species, Glossina pallidipes, Austen, and apparently belongs to an hitherto unknown form.

It is a member of the palpalis group, and seems most nearly related to $G$. tachnoides, Westw., but the markings on the abdomen are not so strong or so sharply defined, and the dorsum of the thorax is buff. It is a female, and measures $8 \mathrm{~mm}$. in length, exclusive of proboscis. In honour of the captor it may be known as Glossina brandoni.

It is my intention to give a detailed description in the next number of the "Annals of the Durban Museum."

E. C. Chubb.

Durban Museum, Natal, June 16.

(Curator).

\section{MUNITION METALS.}

I $\mathrm{N}$ this article an attempt is made to compare briefly the resources of the Allies and the enemy countries in respect of metals which are regarded as essential for War purposes.

First in order of importance comes iron, the basis of the modern gun, armour-plate, armourpiercing projectile, shrapnel shell, high-explosive shell, and all the varieties of steel which find application in one way or another. Both sides have a sufficiency of iron ore and the accessories required for smelting, although the deposits in the enemy countries are inferior in quality to those possessed by the Allies. An illustration of this is furnished by a comparison of the amounts of acid and basic steel produced in Germany and Great-Britain in I9I3-the last year for which the complete figures are available. Germany's total steel production for that year was just under $19,000,000$ tons, of which 96 per cent. was made in basic-lined furnaces; Great Britain's output was $7,66_{3}, 000$ tons, of which only 36 per cent. was made by the basic process. Both countries, however, imported considerable quantities of Swedish pig-iron, which is used for the manufacture of steels of the highest class, e.g., tool steels, and Great Britain also imported substantial amounts of Spanish hematite ore, which was smelted with the clay ironstone ores of the Cleveland district, which are low in iron, and contain, for the most part, more phosphorus than is compatible with the transformation of the resulting pig-iron into steel by any acid process.

The production of open-hearth steel from pigiron-and such steel provides the casing of the high-explosive shell and the shrapnel shell-demands, however, a second and very important metal, namely, manganese, which in the form of ferro-manganese or silico-spiegel is used not only to de-oxidise the fluid steel, but to leave from $0^{\circ} 5$ to $I^{\circ} \circ$ per cent. manganese in the finished product. The chief producers of marketable manganese ore in order of importance are Russia, India, and the United States of America; which in I9I3 furnished about 93 per cent. of the total quantity mined. The raw material is pyrolusite, a "straight" manganese ore corresponding when pure to $\mathrm{MnO}_{2}$. The main supplies of pure ores, therefore, are in the Allied or neutral countries. In I913 Germany imported about 670,000 tons, chiefly from Russia. The figures of her domestic production in 1913 are not available, but in I9I2 her output was 90,980 tons, while that of AustriaHungary was 16,540 tons in 1913 .

In spite of these figures there is no sufficient reason for concluding that the enemy countries will be greatly hampered even if all external sources of supply are shut off, as they probably are. Confining our attention to Germany, the predominant partner, it must be pointed out in the first place that $4,300,000$ tons of her steel production in rgr 3 were exported, and that except in so far as Austria-Hungary and Turkey are concerned this excess would be available for her own 